\title{
Restless legs syndrome and multiple sclerosis
}

\author{
A Brazilian multicenter study and \\ meta-analysis of the literature
}

\author{
Yára Dadalti Fragoso ${ }^{1}$, Alessandro Finkelsztejn², \\ Sidney Gomes 3 , Damacio Ramon Kaimen-Maciel ${ }^{4}$, \\ Celso Luis S. Oliveira', Josiane Lopes ${ }^{4}$, Rafael A. Cristovam²
}

\begin{abstract}
Objective: The increased prevalence of restless legs syndrome (RLS) in multiple sclerosis (MS) has recently been the subject of a few papers. The present study investigated the prevalence of RLS symptoms in MS patients and in controls in four Brazilian cities. Additionally, a systematic review and meta-analysis of the literature was carried out on the subject of RLS-MS. Method: MS patients and controls were investigated regarding the presence of the four typical symptoms of RLS. A questionnaire assessing RLS severity was also used for patients and controls presenting the four RLS symptoms criteria. The systematic review and meta-analysis on the subject were carried out according to the strict international criteria. Results: In the present report, the RLS-MS association was confirmed as being more than fortuitous in Brazilian MS patients, in a multicenter casecontrol study. MS patients also presented RLS symptoms of greater severity than did the control population. A systematic review and meta-analysis of the literature showed that MS patients had a fourfold higher chance of presenting RLS than did the controls. Conclusion: Although underlying mechanisms to explain the association RLS-MS are still a matter of discussion, there is a clear association of these two neurological conditions.
\end{abstract}

Key words: multiple sclerosis, restless legs syndrome, meta-analysis.

Síndrome das pernas inquietas e esclerose múltipla: um estudo brasileiro multicêntrico e metanálise da literatura

\section{RESUMO}

Objetivo: A maior prevalência de síndrome das pernas inquietas (SPI) em esclerose múltipla (EM) foi recentemente assunto de algumas publicações. O presente trabalho investigou a prevalência de sintomas de SPI em pacientes com EM e em controles em quatro cidades brasileiras. Além disto, uma revisão sistemática da literatura e metanálise dos dados foi feita considerando o tema SPI-EM. Método: Pacientes com EM e controles foram investigados com relação aos quarto sintomas típicos de SPI. Um questionário avaliando a intensidade da SPI também foi utilizado para pacientes e controles que apresentassem os quatro sintomas para critério diagnóstico de SPI. A revisão sistemática

Correspondence

Yára Dadalti Fragoso Rua da Constituição 374 11015-470 Santos SP - Brasil E-mail: yara@bsnet.com.br

\section{Support}

All authors have previously received grants for participation in congresses and/or for roles as speakers for pharmaceutical companies relating to neurology

Received 12 April 2010

Received in final form 3 November 2010 Accepted 10 November 2010 e meta-análise do tema foram realizadas de acordo com os rígidos critérios internacionais. Resultados: No presente estudo, a associação de SPI-EM foi confirmada como sendo mais que coincidência nos pacientes brasileiros com EM, através do estudo caso-controle multicêntrico. Os pacientes com EM também apresentaram maior gravidade dos sintomas de SPI que os controles. A revisão sistemática e metanálise da literatura mostraram que os pacientes com EM tiveram quatro vezes mais chance de apresentar SPI do que controles. Conclusão: Embora os mecanismos envolvidos na associação SPI-EM ainda sejam motivo de discussão, existe uma clara associação entre estas duas condições neurológicas. Palavras-chave: esclerose múltipla, síndrome das pernas inquietas, metanálise.

'Department of Neurology, Medical School, UNIMES and MS Reference Center DRS-IV, Santos SP, Brazil; ${ }^{2}$ Department of Neurology, Hospital de Clínicas de Porto Alegre, Porto Alegre RS, Brazil; ${ }^{3}$ Hospital Beneficiência Portuguesa and Hospital

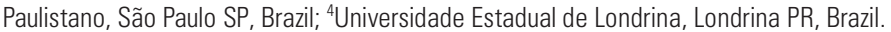


Restless legs syndrome (RLS) is a relatively frequent and underdiagnosed sleep-related movement disorder ${ }^{1}$. The four criteria for considering this diagnosis include: an urge to move the legs (usually accompanied our caused by uncomfortable leg sensations); temporary relief with movement; onset or worsening of symptoms during rest; and worsening or onset of symptoms at evening and/or at night.

Although characteristically described as a primary disease, it can be secondary to a variety of medical conditions. The association of RLS and multiple sclerosis (MS) has been so consistent that it has recently been suggested that MS should be another recognized secondary cause for RLS ${ }^{2}$. During the last decade, a few studies ${ }^{2-6}$ have suggested that the association of these two neurological conditions seems to be more than fortuitous. However, not all authors have agreed with this hypothesis ${ }^{7}$, which left the matter still open to discussion.

The aim of the present study was to assess the prevalence and severity of RLS among Brazilian MS patients. We compared our results with a meta-analysis on the literature on this subject that we conducted.

\section{METHOD}

\section{Brazilian case-control study}

The present study was approved by the Ethics Committees of the institutions involved. Initial approval of the project was obtained by the Ethics Committee of Universidade Metropolitana de Santos, SP. All participants were aged 18 to 70 years and volunteered to answer the questionnaires, and signed a consent to that effect.

MS patients diagnosed according to McDonald's criteria ${ }^{8}$ who were attending the outpatient services of neurological institutions in four different Brazilian cities were included in the study.

Control individuals were recruited from the general population of the same cities, and they were unrelated to the patients. Control subjects claimed to be in general good health. None of the controls had been diagnosed with neurological diseases, except for a few cases of primary headaches. None of the controls were pregnant or undergoing specific treatments for chronic diseases that could influence the prevalence of RLS. Patients and controls were not in use of medications that are known to affect RLS, or undergoing specific RLS treatment.

Individual interviews with patients and controls were carried out between November and December 2009. The presence of RLS symptoms was assessed in accordance with whether they fulfilled the four standard established criteria ${ }^{9}$. The body mass index (BMI) was obtained for each individual from his/her information on weight and height. The severity of RLS symptoms was assessed by means of the Restless Legs Syndrome Rating Scale, val- idated in Portuguese for the Brazilian population ${ }^{10}$. Statistical analysis on all continuous data was performed using the Student- $t$ test. Correlations were assessed by means of the Pearson test. The odds ratio (OR) assessment for the risk of RLS was used to compare the results from MS patients and controls. All confidence intervals were considered to be $95 \%$. Statistically significant differences were considered to be those in which $\mathrm{p}<0.05$. SPSS 16.0 and EpiInfo 6.0 software were used

\section{Systematic review and meta-analysis}

A systematic review of the literature on the subject of MS and RLS was carried out independently by two of the present authors, using Medline, Pubmed, Lilacs, Scielo, Embasco and EMBASE, as well as the reference lists from the relevant retrieved papers. Review papers, congress communications, editorials and studies without control individuals assessed in the same study were excluded. In cases of extension from previous work, only the study with the largest case series was considered. MS patients compared with historical or national databases were not considered in the analysis. Only papers with an English abstract were included. Data extraction was independently carried out by two authors. The fixed effect method was used for meta-analysis. The summarized effect measurement was assessed using the odds ratio of the given event (RLS symptoms). The Comprehensive Meta-analysis Program 2.0 was used throughout the data assessment.

\section{RESULTS}

\section{Brazilian case-control study}

Evaluations of 80 MS patients (60 females, 20 males) and 180 controls (120 females, 60 males) were obtained. The average age for patients was $43.2 \pm 12.4$ years, and $40.6 \pm 15.4$ years for controls $(\mathrm{p}=0.18)$. The average weight was $67.1 \pm 13.4 \mathrm{~kg}$ for patients, and $70.3 \pm 13.5 \mathrm{~kg}$ for controls $(\mathrm{p}=0.08)$. Age and weight were not statistically different between MS patients and controls.

The average history of MS was $7.5 \pm 4.7$ years. Five patients presented the secondary progressive form of the disease, while 75 patients presented the relapse-remitting form of MS. Regarding MS medications, 53 patients were using beta-interferon, 19 patients were using glatiramer acetate, one patient was using natalizumab and seven patients were not undergoing immunomodulatory or immunosuppressive treatment. Patients were not assessed during or immediately after a relapse.

All four standard RLS symptoms ${ }^{9}$ were present in 33 controls and 46 patients $(\mathrm{OR}=6.02 ; 3.36-10.78)$. The severity of these symptoms scored an average of $14.7 \pm 2.5$ in MS patients and 4.6 \pm 16.1 in controls $(\mathrm{p}<0.0001)$. RLS symptom severity for controls was rated as mild $(n=15)$, 
Meta analysis A

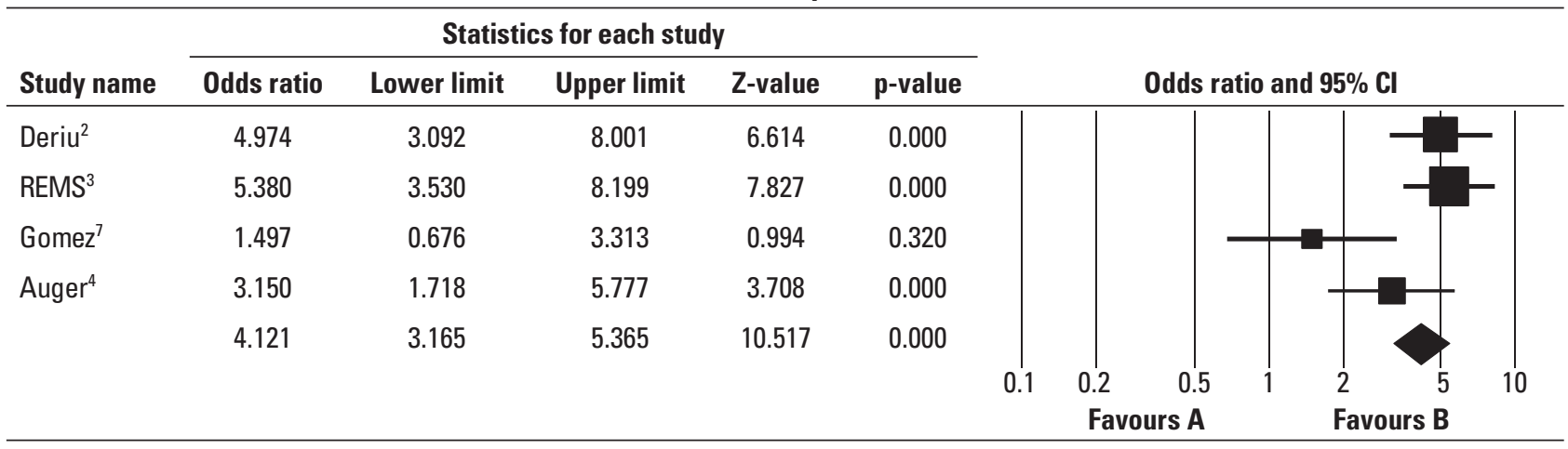

Meta analysis.

Meta analysis B

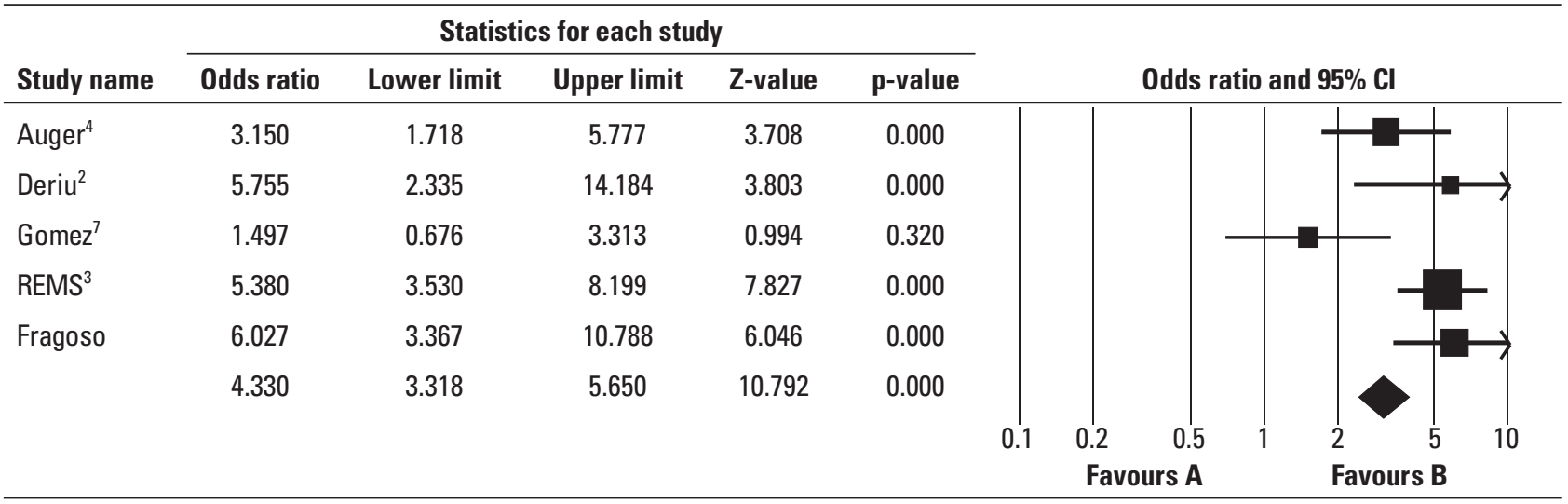

Meta analysis.

Figure. Metanalysis of literature data. [A] Results on four papers published and selected for data extraction. [B] Results including additional data from the present report.

moderate $(n=15)$, severe $(n=2)$ and very severe $(n=1)$. Seven MS patients (five females and two males; none of them overweight) presented very severe RLS symptoms. RLS symptoms in MS patients were rated as mild ( $n=7)$, moderate $(n=23)$ and severe $(n=9)$.

Supposing mild and infrequent RLS symptoms might be affecting the above results, another calculation was carried out. All patients and controls with mild RLS symptoms in the severity scale were excluded, leaving 39 patients (48.75\%) and 18 controls (15\%) with moderate to severe and very severe RLS symptoms for the assessment. Using these data for analysis, the patients showed a five times higher chance of presenting RLS symptoms than did the controls (OR=5.39; 2.76 to 10.48). Disease duration showed no correlation with the severity of RLS symptoms (pearson=0.02).

\section{Systematic review and meta-analysis}

The meta-analysis on the literature is shown in Figure. Four papers assessing RLS in MS according to the abovementioned criteria were identified in the da- tabase search ${ }^{2-4,7}$. Except for the work of Gomez et al. ${ }^{7}$, who could not establish a definitely higher prevalence of RLS in MS patients, all the other three studies showed MS patients to be at higher risk of RLS. The meta-analysis on the reviewed papers showed that MS patients had just under four times $(\mathrm{OR}=3.96 ; 2.94-5.35)$ the chance of presenting RLS than did the control individuals. When data from the present study was added to the analysis, $\mathrm{OR}=4.33 ; 3.31-5.65$.

\section{DISCUSSION}

Although the existence of secondary RLS has long been known, it was only recently that studies on the association of MS and RLS have been carried out. The REMS Study Group underlined the possible methodological flaws of the few other case-control studies on the subject ${ }^{2,4,5}$. However, from the present analysis, it can be seen that the data from all four case-control studies were sufficiently sound to require consideration in the present review of the literature. In addition, evaluations of populations pooled from different countries may provide re- 
sults of greater validity than those from single studies, independent of the degree of comprehensiveness of the methodological design.

The prevalence of RLS symptoms in the present study was very high, both for patients $(57.5 \%$ if mild cases are considered, and $48.75 \%$ if mild cases were not considered) and for controls (18.3\% if mild cases are considered, and $15 \%$ if mild cases were not considered). The population of MS patients and controls assessed here was not particularly old or overweight, in a way that might have explained these results through biased inclusion criteria. The information on weight, height and BMI avoided bias regarding the possibility of RLS symptoms in individuals with higher BMI.

Self-reported mild and infrequent symptoms may have contributed towards these final results ${ }^{3,10-12}$, although all cases presenting RLS fulfilled the four standard criteria for this diagnosis. Notwithstanding the much higher prevalence of RLS symptoms in the Brazilian population of MS patients and controls presented here, the relative risk of RLS in MS remained similar to that observed by Deriu et al. ${ }^{2}$ and by the REMS Study Group ${ }^{3}$.

The present study did not include laboratory exams, neurophysiologic testing or the effect of treatments. Further studies are being carried out, considering these aspects. Paresthesias, weakness and spasticity were unlike to be misinterpreted as RLS symptoms by patients, since all RLS criteria and RLS severity questionnaires were applied by neurologists who cared for these patients. However, similarly to other studies, when patients and controls with dubious, mild or infrequent RLS symptoms were excluded from the calculation, the higher risk of RLS in MS patients persisted virtually unaltered.

It now seems to be indisputable that MS patients are at higher risk of RLS than the general population, further adding to the burden of MS.

\section{REFERENCES}

1. Allen RP, Picchietti D, Hening WA, Trenkwalder C, Walters AS, Montplaisir J. Restless legs syndrome: diagnostic criteria, special considerations, and epidemiology. Sleep Med 2003;4:101-119.

2. Deriu M, Cossu G, Molari A, et al. Restless legs syndrome in multiple sclerosis: a case-control study. Mov Disord 2009;24:697-701.

3. Italian REMS Group. Multicenter case-control study on restless legs syndrome in multiple sclerosis: the REMS study. Sleep 2008;31:944-952.

4. Auger C, Montplaisir J, Duquette P. Increased frequency of restless legs syndrome in a French-Canadian population with multiple sclerosis. Neurology 2005;65:1652-1653.

5. Moreira NC, Damasceno RS, Medeiros CA, et al. Restless leg syndrome, sleep quality and fatigue in multiple sclerosis patients. Braz J Med Biol Res 2008;41:932-937.

6. Douay X, Waucquier N, Hautecoeur P, Vermersch P; G-SEP. High prevalence of restless legs syndrome in multiple sclerosis. Rev Neurol (Paris) 2009;165:194-196.

7. Gomez-Choco MJ, Iranzo A, Blanco Y, Santamaria J, Saiz A. Prevalence of restless legs syndrome and REM sleep behavior disorder in multiple sclerosis. Mult Scler 2007;13:805-808.

8. McDonald WI, Compston A, Edan G, et al. Recommended diagnostic criteria for multiple sclerosis: guidelines from the International Panel on the diagnosis of multiple sclerosis. Ann Neurol 2001;50:121-127.

9. Odin P, Mrowka M, Shing M. Restless legs syndrome. Eur J Neurol 2002;9 (Suppl 3):S59-S67.

10. The International Restless Legs Syndrome Study Group. Validation of the International Restless Legs Syndrome Study Group rating scale for restless legs syndrome. Sleep Med 2003;4:121-132.

11. Masuko AH, Carvalho LB, Machado MA, Morais JF, Prado LB, Prado GF. Translation and validation into the Brazilian Portuguese of the restless legs syndrome rating scale of the International Restless Legs Syndrome Study Group. Arq Neuropsiquiatr 2008;66:832-836.

12. Phillips B, Young T, Finn L, Asher K, Hening WA, Purvis C. Epidemiology of restless legs symptoms in adults. Arch Intern Med 2000; 160: 2137-2141. 